\title{
Turkish Ontological Security In The Early Republic Era: Identity, Regime, and State
}

Yusuf Ziya Bölüikbaşı ${ }^{1}$, Gökberk Yücel*2

Abstract: This study examines under which factors of Turkey's ontological security has been formed and how it has been occurred in the early period of the Republic of Turkey. The main claim of the study is that the national identity, the nation-state, and the Republican regime are inseparable and complementary parts of the Turkish ontological security. This study applies the historical analysis method. In the early period of the Turkish Republic which can be deemed as a process of structural and fundamental changes, Turkey's security concept consists of not only border security. The political regime as a continuation of the aim of protecting the Republic's revolutions, including national sovereignty and secularism, and westernization, constituted the prominent factor of Turkish ontological security. Having said that, considering the new geography vision, policies towards Islamic geographies and Central Asia were considered as revisionist and it was aimed that the protection of the status quo both in and outside the country. In accordance with the territorial state model, the Turkish biographical story was reconstructed with the nation-state models as the framework of the national society and the national society itself, and therefore it was accepted as the integral parts of the Turkish ontological security.

Keywords: Ontological Security, Identity, Kemalism

\section{Erken Cumhuriyet Döneminde Türk Ontolojik Güvenliği: Kimlik, Rejim ve Devlet}

Özet: Bu çalışmada erken Cumhuriyet döneminde Türkiye'nin ontolojik güvenliğinin hangi faktörler çerçevesinde ve nasıl oluştuğu incelenmiştir. Bu noktada Milli kimlik, ulus devlet ve Cumhuriyet rejiminin Türk ontolojik güvenliğinin ayrılmaz ve birbirini tamamlayıcı parçaları olduğu çalışmanın temel iddiasıdır. Tarihsel analiz metodunun kullanıldığı çalışmada yapısal ve köklü değişimlerin yaşandığı bir süreç olarak erken Cumhuriyet döneminde Türkiye'nin güvenlik konsepti sadece sınır güvenliğinden oluşmamaktadır. Başta milli egemenlik ve laiklik olmak üzere Cumhuriyet devrimlerinin korunması ve batılılaşma gayesinin devam etmesi noktasında siyasal rejim Türk ontolojik güvenliğinin birinci faktörünü oluşturmuştur. Bununla beraber yeni coğrafya vizyonunda İslam coğrafyalarına ve Orta Asyaya yönelik politikalar revizyonist kabul edilmiş hem ülke içinde hem de ülke dışında statükonun korunması hedeflenmiştir. Territorial devlet modeline uygun olarak Türk biyografik hikayesi milli toplum ve milli toplumun çatısı olarak ulus devlet modelleriyle yeniden inşa edilerek Türk ontolojik güvenliğinin tamamlayıcı parçaları olarak kabul edilmiştir.

Anahtar Kelimeler: Ontolojik Güvenlik, Kimlik, Kemalizm

\footnotetext{
${ }^{1}$ Anadolu University, Department of Political Science and Public Administration, Eskisehir, Turkey, yzb@anadolu.edu.tr, ORCID ID: 0000-0003-4723-5977

${ }^{2}$ Amasya University, Department of Political Science and Public Administration, Amasya, Turkey, gokberk.yucel@amasya.edu.tr, ORCID ID: 0000-0002-0299-1722

Received: 01 March 2021, Accepted: 15 March 2021, Online: 30 April 2021

* Corresponding Author
} 


\section{Introduction}

The concept of ontological security consists of the identity that the agent has built on the basis of his/her biographical narrative; the threat of the other that appears in line with the position of the identity, and the attitude and behavior s/he exhibits against this threat. This study aims to discuss what elements constitute the ontological security of the Republic of Turkey and how it is shaped in the early period of its establishment. In this context, the following elements were chosen as the basic elements in explaining the Turkish ontological identity: the modern Turkish identity, the Turkish nation-state which is the embodiment of identity, and the republican regime which is dependent on Western norms and values. Although several scientific studies on national identity, modern state, and construction of regime exist in the academic literature in Turkey, these phenomena will be discussed on the concept of ontological security in the present study. The western and realist grounds in the shaping of the identity, state, and regime after the Ottoman Empire paved the way for the Turkish biography to be rewritten with both historical and geographical imaginations. In this context, it is assumed that the question "Who is a Turk?" is the answer to the question "What is Turkish ontological security?" in the equation of history, geography, and identity.

First, the conceptual framework of ontological security will be explained briefly in this study. Then, the understanding of the state and security inherited from the Ottoman Empire will be examined in the context of the historical background of Turkish ontological security. Such an examination is thought to be significant in terms of understanding the influence of the fallen Ottomans on the ontological security of the early Republic period. Finally, the understanding of ontological security in the early years of the establishment of the Republic will be discussed. Turkish ontological security in the early Republican period era will be scrutinized under three headings. The first one is the establishment of the Western-type territorial state connected to the land with all its elements.

The second one is the determination of the limitations of this state in the form of the nation-state and the context of national identity. Finally, the last one is the preservation of the Republican regime depending on the slogan of national sovereignty and civilized society.

The historical analysis method was used in this study. The historical analysis involves the study and analysis of controversial ideas and facts, and aims to evaluate the meanings and analyze the messages about events while asking the questions "what happened?" and "why?" or "how?" (Leedy \& Ormrod, 2015). Besides, discourses were analyzed by including some speeches of the actors of the period. 


\section{Theoretical Framework: Ontological Security}

In the classical sense, the concept of security consists of the intellectual and behavioral concept aimed at protecting the physical/material existence of the agent and ensuring its permanency. However, this definition on its own is insufficient to define security since the place where the agent is located and the factors that form the personality of the agent also give clues about what to perceive as a threat and what kind of a reflex will be shown as regards to this threat. In this context, the problematic regarding who the agent is, together with the threat and defense tools that constitute the other components of security, reveals a new approach to security: Ontological security. Anthony Giddens (2014, s. 75) bases the concept of ontological security on the individual's search for identity and sense of self and the biographical narrative that emerged as a result of these quests. Biographical stories are shaped constructed through a holistic memory with an action setting for the future. However, in the selves where the agent/act relationship is defined and completed in a satisfactory way, clear and obvious answers are given to the questions such as which components of ontological security should be secured, why should security be provided, and finally how security should be established. Instead of being based on given or periodic constants, these answers are formed by an identity-threat-reflex equation that can be changed, transformed and continuous at any time, (Kinnvall, 2004, s. 745). Therefore, the different and continuous use of the people, events and concepts selected from the memory reservoir in the construction of the biographical narrative will entail different perceptions of identity, different spatial explanations, and threat perceptions through this concept. However, it will strengthen a sustainable, predictable, and controllable sense of trust while controlling anxiety towards existence (Kinnvall, 2004, s. 746).

While the biographical narrative answers the question "Who am I", it also highlights the concept of the other, which is the complementary element of this answer. The other is perceived as the threat that the agent positions in the insecure area against the assets, values, and moral values. The other is also one of the elements of the identity bond that the agent will create his/her awareness. In this context, a stable and intelligible combination of language and action in the past, present, and future will establish the notion of a strengthened identity (Güç, 2018, s. 64). Space is the area where the biographical narrative concretely produces the identity it has established on memory and language. The space is full of natural or artificial spaces or artifacts that demonstrate the outcomes of the agent/act relationship and allow it to be remobilized in identity construction. Therefore, the confidence, peace, assurance provided by "insideness" and the fear, anxiety, and threat brought about by "outsideness" are the natural outcomes of the space-identity-memory equation (Seamon \& Sowers, 2008, s. 44-46). 
Ontological security also produces an answer to the question of who we are as the subjects of security on the ground of the state. The modern state consolidates its sovereignty over the land territory with its boundaries in the common biographical narrative that it constructs by through processing the collective memory. In this context, the security of the states does not consist merely of border security. The biographical narrative selected and processed by the state from the memory of the society and the national identity, political structure, and instruments determined by this narrative become a part of ontological security (Mitzen, 2006, s. 344-345; Zarakol, 2016, s. 2-4). In this context, existing political actors legitimize the political system they have built and the national identity they have built backward through this system based on ontological security (Rumelili and Adisönmez, 2020, s. 29). At this point, the national identity formed in the meaning and definition of society and the ideological construct, political structure, and future goals of the state are integrated as a result of nationalism. In other words, national identity, constructed as the answer to the questions of when we existed as collective memory and where did we come from on the topic of common geography, is transformed into a future perspective with common concerns, goals, and objectives (Subotic, 2016, s. 612). Therefore, political preferences regarding the preservation and continuity of national identity are produced by the state within the scope of ontological security, and the citizens of the country are expected to protect these preferences and express loyalty (Tetik, 2018, s. 108).

\section{Ontological Security Approach in The Early Republic Period Era}

\subsection{Historical Background of Turkish Ontological Security}

The most fundamental motivation of the classical Ottoman system was to establish order in the world and the continuity of the state within the framework of preserving it. In that sense, it is safe to argued that two forms of order existed: outward-oriented and internal. The former refers to establishing order and harmony in the world while the latter is establishing order and harmony within the state. In this context, external-oriented order policies had a universal claim in the understanding of "order of the world". The idea of the state of eternity (Devlet-i ebed müddet ${ }^{1}$ ) was based on the understanding that the state exists forever for the order of the world (the distribution of justice to the whole world). In other words, the security of the state was regarded as the insurance of the order of the foreign world.

The positioning of the Turkish state in a central place in the context of the world state model led to the

\footnotetext{
${ }^{1}$ It means that the state would last forever, and to describe the continuity of the Turkish State established throughout history.
} 
establishment of a hierarchical relationship with other countries. In this context, the West had an identity that was often regarded as an understatement and not considered an equivalent power. However, there was a balance between Europe and the Ottoman Empire from 1606 The Treaty of Zsitvatorok to the Treaty of Küçük Kaynarca signed in 1774, (Karpat, 2012, s. 29). Furthermore, after the Russo-Turkish War between 1768 and 1774, the Ottoman Empire went through a huge crisis of existence, and it was accepted that European states established superiority over the Ottoman in every field. Then, the Ottomans realized that they were not able to compete with and balance against Europe (Neumann, 2019, s. 231). This situation process resulted in only one option for the Ottoman Empire: "Modernization and Westernization" (Lewis, 2015).

For the Ottomans, who felt that they need to become Western in order to accept the superiority of Europe and abolish backwardness, this concern was a technical adaptation rather than changing the circle of civilization. In fact, partial movements towards Westernization had started in the Tulip Period and continued with Nizam-i Djedid. As the first Westernizing institution, the army has occupied a central place as the most important actor of Turkish modernization until today. The beginning of the westernization movement extended the life of the state, which to some extent came to an end, for a certain period. Setting up Embassies in European capitals, integration into the European balance of power system and the effort to establish relations with European countries under equal conditions were important attempts for the continuation of the state's existence (Tunaya, 2016, s. 17-25). In sum, Westernization was placed at the center of ontological security as the construction and implementation of security for Ottoman foreign policy.

As a result of the Acts of Vienna Congress of 1815 signed at the end of the Napoleonic Wars, the system of "Balance of Powers" emerged in Europe, and within this system, the Ottoman had the opportunity to cooperate with several states. Nevertheless, with this agreement, the Ottoman Empire was seen as a passive and weak country, and could not have a playmaking function in the international system. In fact, the biggest problem for the Ottomans was their survival in that they tried to survive instead of being a playmaking actor (Okman, 2012, s. 268). In this period, the independence of Greece, the uprisings in the Balkans, and the defeats against the Egyptian Governor propelled the state into a process of collapse, and modernization had become obligatory to prevent this. According to Ahmad (2019, s. 33), the Westernization movement of the Ottoman Empire started with the integration of its economy into the capitalist system with the Treaty of Balta Liman (the Anglo-Ottoman Treaty) signed with Great Britain in 1838. The 1839 Tanzimat Reform Edict (Edict of Gülhane) is accepted as the starting point of Ottoman-Turkish modernization in the literature. The Tanzimat Reform Edict is regarded as the first text in which the idea of the modern state 
emerged, with its reference to individual freedom and the acceptance of the understanding of equality among the Ottoman subjects and preventing arbitrary administration. To prevent the intervention of by Western states in the internal affairs of the Ottoman Empire, some Western-oriented institutions were established as a part of this edict (Tunaya, 2016, s. 29-34). With the 1856 Paris Treaty signed after following the 1854 Crimean War, the Ottoman State was considered among the European states and it was stated that the territorial integrity of the Ottoman State and its territorial integrity was guaranteed by the European states. However, protecting the territorial integrity of the Ottoman Empire and accepting it as a European state remained in theory and was never put into practice (Akşin, 2019, s. 33). However, being regarded among the as a European state set up the goal of Ottoman-Turkish modernization concerning establishing state security which continues even today. With the Treaty of Paris, 1856 The Imperial Reform Edict was issued, and the rights declared in the Tanzimat Reform Edict were progressed forward. After that time, the modernization of the political regime became the primary aim and as a result, the First Ottoman Constitution of 1876 was accepted in 1876 and the Constitutional Monarchy was declared subsequently after the first elections. After the Russo-Turkish War of 1877-1878 between the Ottoman and the Tsardom of Russia, known as War of 93 in history, Abdul Hamid II put an end to the constitutional administration, then in 1908 he had to declare the Second Constitutional Era. During this process, Westernization was used as a synonym for liberty (Tunaya, 2016, s. 38-41). However, a large amount of discussion about Abdul Hamid II's style and policies exists in the literature. In foreign policy, the dominant opinion is that Abdulhamid II was a leader who was able to carry out the balance policy successfully (Kreiser, 2019a, s. 266). In other words, he tried to guarantee the loyalty of the inside Muslims by using the Caliphal authority. He preferred to stay neutral until the last period of his reign and carry out a pacifist, impartial and isolationist policy that shaped the foreign policy of the Republic (Karpat, 2012, s. 52-57). Also, modernization moves sustained in the reign of Abdulhamid II. However, the modernization moves process entered a new stage during the Second Constitutional Era and the reign of the Committee of Union and Progress (CUP) that started afterward. Kraiser (2019: 278) states that secular reforms, particularly in the field of law, education, and central administration, were put in place during the CUP period. Although the superiority of the West was acknowledged and the westernization moves turned out to be a part of the ontological security of the state, the CUP era was the period when the European balance of power system came to an end (Cengizer, 2017, s. 462). The officers of the CUP tried to eliminate the threats against the state by joining World War I alongside Germany upon the agreement of the great states in solving the Eastern Question which resulted in the fragmentation of the Ottoman lands. During the CUP period, the state fought for national independence: first in World War I, and then in the Turkish War of Independence. 
The basic dynamics of Turkish ontological security such as modern national identity, nation-state, and national sovereignty on the way to the Republic began to mature in this period. The historical memory of the state-identity unity in Turks had been redesigned in the cultural and political field. Integrating the intellectual and institutional experience of Ottoman modernization to the state-identity unity, the ontological security of the republic was established after Turkish War of Independence. In this context, Turkish ontological security transformed from a struggle for independence to a struggle for the future and as a result modernization became the founding element of the struggle for the future.

\subsection{The Components of Turkish Ontological Security: Nation-State, National Identity, and Repub- lic Regime}

The security conception of the founder of the Republic of Turkey Mustafa Kemal Ataturk can be regarded as having primary importance in all the studies on Turkey since. In Anscombe's words (2017, s. 261), Turkey is "the legacy of Atatürk". This situation is not only due to Atatürk's prominence and the victories he claimed at the fronts by starting the Turkish War of Independence, but it is also a reflection of the efforts to for constructing a Turkish national identity and establish a strong state, which was the dream of Ottoman modernizers (Anscombe, 2017, s. 256-261). The ontological security in the early Republican period emerged on two grounds: nationalism and civilizationism. According to Akşin (2019, s. 88), Atatürk's world of ideas was extremely Westernist and nationalist. Therefore, it can be argued that Atatürk's ideological tendency is a synthesis of nationalism and Westernism. According to Sander (2006, s. 154), from the beginning of the Turkish War of Independence, the Ankara government had three goals in foreign policy: independence, sovereignty, and establishment of security. However, during this period, Ankara did not end its relations with the West even while fighting against it and implemented a Westernist foreign policy in achieving its goals.

\subsubsection{From the Universal State Model to the Territorial State Model}

During and after the Turkish War of Independence, the most fundamental principle of the struggle for independence was to abandon the universal state model and build a western-type territorial state. In this context, the early Republican period was based on the obligation of total independence, balance politics-realist approach, and keeping away from Pan-Nationalist movements. Thus, Mustafa Kemal Atatürk stated the following in a statement he gave to National Sovereignty newspaper on April 22, 1921:

"Freedom and independence is my character... In order to survive, I must remain a son of an independent 
nation. Hence, national independence is a matter of survival." Foreign affairs were also centered on the principle of commanding respect for independence: "Similar to any independent state, Turkey will have its rights recognized. The Treaty of Sèvres is such an evil decree for the Turkish nation that we prefer it not to be a demand of a friend. We cannot develop relations based on trust with nations which do not dismiss the Treaty of Sèvres out of their mind”. In addition to the prominence of independence, Atatürk's realist approach also shaped the politics of the period. In the very early stages of the Turkish War of Independence on 10 November 1919, in the a letter he sent to Bekir Sami Bey, the Commander of the 56th Division, who was in Bursa at that time, he stated: “(... In conclusion, I have to say that we should not support any side. We have to clearly tell all of them that we will not consent to their purpose, that is, the destruction of our motherland, and that it is our aim to ensure the independence of our state... Today we have no friends. However, our friend is our national unity and our organization, Sir”. Atatürk's realist approach also reflects itself concerning the occupying of Western powers and rapprochement with the Soviets: "First we prioritize our own strength. However, considering the number of our enemies, it is a must to strengthen our own force. Thus, we will, of course, approve the positive forces to be expected to come from the East. Nevertheless, at this point, it is crucial to make a distinction between the two aspects: the first one is to be Bolshevik and the other is to ally with Bolshevik Russia. We, the cabinet, are talking about allying with Bolshevik Russia but not talking about being a Bolshevik... We should not be afraid of the West anymore, there is no need to fear. Until we see that day, and until the force coming from the East materially aids us, having all kinds of political relations with the West cannot stop us from engaging in political relations with any state from the East” (Atatürk, 2018, s. 153, 158, 68-69, 110-111).

The newly founded Republic regime disclaimed its rights in the Ottoman hinterland and rejected revisionist/irredentist policies. Atatürk reflected this reality in his speech to the public in İzmir on February 2, 1923:

“Yet, under the name of this "Eastern Question", the existing opinion on the subject of entirely destroying the Ottoman state and the Turkish element, the Turkish nation, which established states and had the power to establish great empires, is very deep... The West does still not want to admit the truth and acknowledge that the former Ottoman state was destroyed and the new Turkish state has emerged. Such a Turkey has emerged with its own freshness, faith, determination, and power. And it will use all these characteristics to take revenge against those who have victimized and persecuted itself. Friends, when I talk about revenge, it should not be assumed that we will take revenge by attacking hither and thither, by making long 
operations, by violating the lands and benefits of some people and some nations as done in several periods of the Ottoman Empire. No! ... It is not the existing notion of the new Turkey and its government and the nation that created and established it".

On the other hand, the balancing policy and the realist approach centered a foreign policy under the spirit of the territorial state model. The Ankara government, which implemented the Soviet against the West and the West against the West policy during the Turkish War of Independence, carried out a realistic foreign policy strategy on condition that it took advantage of the conflicts of interest between the powerful states of the period (Oran, 2011, s. 107-109). Gönlübol and Sar (1996, s. 59) stated (state) that after the Turkish War of Independence, Turkey was forced to follow a realist foreign policy since Turkey had borders with all the western states of the period (Britain, France, and Italy) and with the USSR. As a matter of fact, there were seven independent non-Western states -except for Japan- in this period: China, Thailand, Afghanistan, Iran, Arabia, Ethiopia, and Turkey. Among them, the only state that was able to preserve its independence in the real sense was Turkey (Ahmad, 2019, s. 91).

Ataturk's realistic approach was shaped within the framework of national security and national interests of Turkey and it was grounded on the distinctive feature of abandoning the revisionist politics during the Turkish War of Independence. In this context, the National Pact (Misak-1 Millî) borders provided the basis of the territorial state. With the Treaty of Lausanne of 24 July 1923, the borders of the fully independent territorial state were established except for such provinces as Mosul, Kirkuk, and Batumi. Turkey's primary aim in this process was to ensure the maintenance of the obtained status. In this juncture, the territorial state model carried out status quo policies based on the establishment of the Republic of Turkey's border security. In the context of guaranteeing the security and the presence of Turkey, the symbol of status quo politics was the statement of "Peace at Home, Peace in the World" which was expressed for the first time in 1931 by Ataturk (Gönlübol and Sarr, 1996, s. 92-94).

The two events that disrupted the status quo created in the Treaty of Lausanne in favor of Turkey were the 1936 Montreux Convention Regarding the Regime of the Straits and 1939 Hatay's Annexation to Turkey. Rather than being a revisionist and aggressive political gestures, both events emerged in the context of strengthening Turkey's independence and sovereignty. However, the Montreux Convention Regarding the Regime of the Straits was called as "revision through negotiation" (Aras, 2013, s. 165) whereas Hatay, which remained outside of the borders determined in the National Pact in The Treaty of Lausanne, was annexed to the motherland with "the legal revision" for the security of southern Turkey. 


\subsubsection{Ontological Boundaries of the Territorial State: Nation-State Identity}

In the early Republican period, a transition from the Ummah community to the national community took place, and the development of a Western-secular Turkish identity was sought after with Kemalist revolutions. In this process, the understanding of nationalism - the official (Kemalist) nationalism - on which the state was founded, was based on the framework of the ideal of civilization by taking intellectual and institutional aspects of the modernization process into consideration altogether. State-centered official nationalism, which was compelled by the intention of transforming society into a Western structure, formed the political aspect of Turkish identity in the Turkish Constitution of 1924 in the first place, and later, an ethnocentric and secular identity was established through the Turkish History Thesis and Sun Language Theory, which were proposed based on certain anthropological approaches adopted in the 1930s (Durgun \& Yücel, 2019, s. 192- 193). At this point, in the Turkish History Congress held between 1932 and 1937, it was claimed that the civilization in Anatolia was established by the civilized Turkish community who migrated from the north of Central Asia before the ancient ages Before Christ (BC), and in this vein, the Sumerians in the Near East and the Hittites in Anatolia were Turks. Therefore, Anatolia was regarded as the ancient motherland of civilized Turks (Galip, 1932, s. 109-115, 164; İnan, 1932, s. 18-24). Such a consideration also represents an antithesis to the idea that the Turks made their first entrance in Anatolia with the Battle of Manzikert in 1071 after the adoption of Islam. Certainly, this consideration also epitomized that there was no particular interest in the geography of Turks or non-Turkish Muslims outside of Anatolia. Moreover, the fourth article of the instruction sent to Sivas Province and Committee of Delegations on March 4, 1920, was as follows: ”To declare in the publications about the Islamic world that, by avoiding the propaganda of Turanism and Pan-Islamism, the movements in Asia are only activities aiming to attain independence by Muslim nations within their borders and nationalities”. Atatürk expressed the need to abstain from Pan-Islamism in the letter he wrote to Enver Pasha on October 4, 1920, as follows: “(...) To avoid showing the efforts and actions in the unification and organization of the national movement, which is about to be born at the moment in Islamic countries such as Turkistan, Afghanistan, and Persia, as well as the goals and objectives to be guided in this way in the form and form of Pan-Islamism so as not to arouse suspicion and concern for the Russians ..." (Atatürk, 2018, s. 204, $211,90,128)$. These statements should not be regarded merely in the context of Russian doubts supporting the Ankara government during the Turkish War of Independence or not meeting with the reaction of all Western states. Thus, Atatürk did never have a positive look on "Pan-nationalist" movements after the

establishment of the Republic and regarded them as adventurous by saying that "It has not been seen in history that Pan-Islamism and Pan-Turanism politics have succeeded and made the world a field of 
application"(Atatürk, 2006, s. 299). In this respect, it can be stated that the idea of the motherland in the early Republican period was limited to the Anatolian geography and the early Republican period regarded the international brotherhood movements irrational.

The process of constructing Turkish national identity in the early republican period can also be regarded as a part of ontological security as a strengthening element of the territorial state model. Forming a superior identity that covers all segments of society against religious and ethnic separations would secure the formation of a common national consciousness in the context of commitment, loyalty, and obligations to the state. This national consciousness was intended to be incorporated with the concept of citizenship. Therefore, Turkish citizenship also constituted the forms and patterns of affiliation to the Turkish identity. Another reason for avoiding "Pan-Nationalist" movements was the citizenship institution that was intended to be brought about in a particular geography. In this context, awareness and identity of citizenship provided the basis for state-nationalism (Durgun, 2010). The nation was considered as a community of people sharing the same motherland and influencing the future of the same state, which led to the transformation of the national identity into the identity of the nation-state. Therefore, protecting the national identity was regarded as being equal to protecting the nation-state identity at the same time. The design of the nation-state identity in agreement with the political validity of the age was a manifestation of the desire to establish a sociology of society that was, to some extent, compatible with the reality of the age.

\subsubsection{The Ontological Spirit of the Turkish Nation-State: The Republic Regime}

Another characteristic that established the spirit of the early Republican era's nation-state identity and considered it as one of the most important components of Turkish ontological security was the Republican regime. The republican regime emerged as the necessary principle of the national identity in the context of national sovereignty and the modern state identity in the context of westernization. The principle of national sovereignty reinforced the national identity in terms of strengthening citizenship ties and the effectiveness of the community in the administration of the country. It is fair to argue that the Amasya Circular, issued at the beginning of the Turkish War of Independence on June 22, 1919, constituted the birth certificate of the republic with the first article stating that the future of the country is in the will of the Turkish nation (Taşdemir, 2005, s. 1084-1085). In the relevant article, the same article stated that the motherland and the national survival are in danger, and it is emphasized that this dangerous process can be overcome with the determination and solidarity of the nation and that a national committee must 
be formed to represent the nation (TBMM, 2015, s. 11). The formation of the national committee was completed at the Sivas Congress on September 4, 1919, under the name of Association for the Defense of National Rights of Anatolia and Rumelia, and both the administration and conduction of the Turkish War of Independence was carried out in the Grand National Assembly, opened on April 23, 1920, with the participation of delegates from all over Anatolia. Additionally, the Republic regime was bolstered within the framework of the principle of national sovereignty with the abolition of the Ottoman sultanate in 1922 and the abolition of the Caliphate in 1924.

Republicanism was addressed based on national sovereignty in the first article of the 1923 by-law of the Republican People's Party, the first and establishing party of the republic. Similarly, in the 1927 by-law, national sovereignty was regarded as the common denominator of republicanism, nationalism, and populism (Erdoğan, 2000, s. 19- 23). Republicanism was included in the format of the "Kemalism" ideology in the 1931 by-law and program and the 1935 Party program (CHF Nizamnamesi and Programı, 1931, s. 31; CHF Programı, 1935, s. 4).

Another component of the Republican regime is Westernism. Westernism projected the adaptation process to the Western civilization not only in terms of science and technique, but also politically, socially, and culturally. Therefore, the preservation of the republican regime was evaluated on the same ground with the state's aim of reaching the level of contemporary civilizations. However, the fact that the Kemalist revolution had the political targets similar to European countries arouse from the requirement of cooperation with the West for economic development and Turkey's feeling of necessity to be a member of the European community of nations against the further threat of dissolution or extinction (Sander, 2006, s. 155). Nationalism based on the concept of a nation-state was considered as a step and means of civilization (Durgun, 2010). In consequence, the following statement of Atatürk proves this: "Today, twice eight is sixteen. If ten people said that and a hundred people insisted on ten, would we accept what a hundred people said?... We are now Westerners" (Tunaya, 2016, s. 98). In addition, this statement reflects the Jacobin character of Turkish modernization and Atatürk's positivist approach. Indeed, the whole structure of the Ancien Régime was replaced with the Western institutions in this process, and, as Tunaya (2016, s. 18) stated, Westernism became a means of moving from ancient civilizations circle to a new one for Turkey. For this reason, first, the political structure and then the legal regime were changed ${ }^{2}$. Therefore, Kemalist modernization demanded a total modernization in political, economic, and social terms, visualizing to

2 , the Sultanate was abolished on November 1, 1922, the Republic was proclaimed on October 29, 1923, the Caliphate was abolished on March 3 , 1924, and Law on the Unification of Education was adopted on the same day. Sharia courts were abolished on April 8, 1924, and the Turkish Constitution of 1924 was ratified on April 20 . This process proceeded with the closure of religious covenants and dervish lodges on November 30, 1925, the adoption of the Civil Code on February 17, 1926, the removal of the statement "the religion of the state is Islam" from the Constitution on April 10, 1937, and the inclusion of the secularism principle into the Constitution with the six arrows on January 5 , 1937. (Akşin, 2019, s. 185-188). 
govern the state with the secular ideology of the 20th century instead of traditional methods. Developing a new identity with the technology, materialism and intellectual understanding of the West was the most important prominence of Kemalist modernization. In this context, it was aimed to impose a secular order in which religion was controlled by the state rather than a structure where religion was separated from the state (Ahmad, 2019, s. 90). In that sense, the full discussion broke out about the relationship among religion-society-politics-state. Atatürk justified the abolition of the Caliphate and the establishment of Western institutions instead of religious structures with the reason that religious structures posed an obstacle in the path of development (2018, s. 227). According to Parla (2008, s. 259-271), who examined the programs of the Republican People's Party, Atatürk aimed to develop an understanding of Islam that is free of all superstitions, modern and will guide the conscience. Also, it is seen that religious institutions were abolished within the framework of political purposes, as well as since they hinder the principle of secularism and modernization. In other words, the structures that were expected to oppose the new regime were the religious institutions of the former system, and their abolition meant that the opposition was also destroyed. However, in the end, destroying the religion was not the goal, instead, Ataturk's revolutions aimed to nationalize the religion (Anscombe, 2017, s. 262). Nevertheless, the most fundamental aspect of Atatürk's Reforms was that they brought more attention to cultural progress than technical progress (Kreiser, 2019b, s. 317). In other words, institutionalism indicates much more importance for Atatürk. This situation originates from Atatürk's nationalist ideology and his goal of contemporary civilization.

The regime's reflex of protection and defense become concretely apparent with the 1925 Sheikh Said Rebellion, the 1930 Menemen Incident, and the 1937 Dersim Rebellion. The rebellions were regarded as separatist and dissociative movements against the Turkish existence, the Turkish motherland, and the Turkish Republic (Atatürk, 2006, s. 604).Therefore, the security of the regime was considered as an integral part of border security (Goloğlu, 2011, s. 117). For example; this issue was expressed as follows in the law of Takrir-i Sükûn (Law on the Maintenance of Order) enacted by Ismet Pasha on 3 March 1925 (Zabit Ceridesi, Vol.15, s. 131):

"With the approval of the President, the Government is authorized to, on its initiative and by the administration, ban all organizations, provocations, incentives, attempts, and publications that are reactionary, rebelling and that attempt to violate social order, peace, and quiet, security, and order of the country. The government may entrust those who committed these acts to the Independence Tribunal." 


\section{Conclusion}

The Turkish identity was centered on Turkish ontological security in the early Republican Period. At this point, Turkish identity was formed in a Westernist-territorial form through a new conception of historiography and geography. The Anatolian centricity and Western orientation in the modern Turkish identity rejected the "pan-nationalist" movements related to the Middle East, the Caucasus, and Turkistan that formed the Ottoman hinterland. On the other hand, Turkish identity was strengthened by the territorial and nation-state structure.

The modern Turkish identity, reinforced by the nation-state structure, featured the republican regime in Turkish ontological security in the context of national sovereignty and adaptation to the civilized world. The defense and protection of the Republican regime against external and internal enemies presented a loyal citizenship profile devoted to Atatürk's principles and revolutions. In this context, while Turkish citizens achieved a position to become effective in the administration and future of the country, the Sultanate and the Caliphate were regarded as threats to Turkish ontological security as the other of the Republican regime. In this respect, the republican regime and the nation-state structure intertwined and established a kind of "state nationalism". In other words, Turkish nationalism, which united all citizens in the country and became a new turning point towards westernization, transformed into Turkey nationalism.

Finally, the security of the state transformed from a narrow conception of security such as border security into a comprehensive one that including all the elements of the Republic of Turkey. In the line of this concept, the territorial state model instead of the universal state model; nation-state identity against the Ummah or the "pan-nationalist" conception of the nation; and the republican regime, rejecting the Sultanate and the Caliphate in the context of national sovereignty and Westernization ideals, constructed the elements of Turkish ontological security.

\section{Kaynaklar}

Ahmad, F. (2019). Bir kimlik peşinde Türkiye. Translator S. Cem Karadeli. İstanbul: İstanbul Bilgi University Press.

Akşin, S. (2019). Kısa Türkiye tarihi. İstanbul: Türkiye İş Bankası Kültür Publishing.

Anscombe, F. F. (2017). Osmanlı Dönemi ve sonrası ülkelerde devlet, inanç ve millet. Translator C. Can Aydın. İstanbul: Alfa Publishing. 
Aras, T. R. (2010). Atatürk’ün dış politikası. İstanbul: Kaynak Publishing.

Atatürk, M. K. (2006). Nutuk. Z. Korkmaz (Ed.). Ankara: Atatürk Research Center Publishing.

Atatürk, M. K. (2018). Atatürk’ün kaleminden 7: Emperyalizm ve tam bă̆ımsızlık. M. Sarıkaya (Ed.). İstanbul: Kaynak Publishing.

Cengizer, A. (2017). Adil hafizanın ışı̆̆ııda Osmanlı’nın son savaşı (3rd ed.). İstanbul: Ötüken Publishing. CHF Nizamnamesi ve Programı. (1931). Ankara: TBMM Publishing.

CHP Programı. (1935). Ankara: TBMM Publishing.

Durgun, Ş. ve Yücel, G. (2019). Türk Milliyetçiliği: tanım, teori ve süreç. Ö. Baykal (Ed.). Cumhuriyet Döneminde siyasi düşünce. Ankara: A Kitap, 181-209.

Erdoğan, A. (2000). CHP tüzüklerinin dünü ve bugünü 1923-2000. Ankara: V Kitap.

Galip, R. (1932). Türk ırk ve medeniyet tarihine umumi bir bakış. Birinci Türk tarih kongresi konferans müzakere zabitları (2nd ed.). Ankara: Türk Tarih Kurumu Publishing, 99-164.

Giddens, A. (2014). Modernite ve bireysel kimlik geç modern çă̆da benlik ve toplum (2nd ed.). Translator Ü. Tatlıcan. İstanbul: Say Publishing.

Gönlübol, M. ve Sar, C. (1996). 1919-1939 dönemi. Olaylarla Türk dış politikası. Ankara: Siyasal Kitabevi Press, 3-137.

Güç, K. (2018). Bireyden devlete varlıksal (ontolojik) güvenliğin taşıyıcı sütunu: Biyografik hikâye. M. Akif Okur (Ed.). Güvenlik, kargaşa ve belirsizlik çă̆ında nereye?. İstanbul: Kocav Publishing, 61-76.

İnan, A. (1932). Tarihten evvel ve tarih fecrinde. Birinci türk tarih kongresi konferans müzakere zabıtları (2nd ed.). Ankara: Türk Tarih Kurumu Publishing, 18-41.

Karpat, K. (2012). Türk dış politikası tarihi. İstanbul: Timaş Publishing.

Kinnvall, C. (2004). Globalization and religious nationalism: self, identity, and the search for ontological security. Political Psychology. 25 (5), 741-767.

Kreiser, K. (2019a). Son Osmanlı yüzyılı (1826-1920). K. Kreiser ve C. H. Neumann (Eds.). Küçük türkiye tarihi. Translator Y. Emre Gürbüz. İstanbul: İletişim Publishing, 241-293. 
Kreiser, K. (2019b). Yeni Türkiye (1920-2002). K. Kreiser ve C. H. Neumann (Eds.). Küçük Türkiye tarihi. Y. Emre Gürbüz, İstanbul: İletişim Publishing, 293-371.

Leedy, P. D. ve Ormrod, J. E. (2015). Practical research: planning and design. London: Pearson.

Lewis, B. (2015). Modern Türkiye’nin doğuşu. Translator B. Turna, İstanbul: Arkadaş Publishing.

Mitzen, J. (2006). Ontological security in world Politics: State identity and the security dilemma, European Journal of International Relations. 12 (3), 341-370.

Neumann, C. H. (2019). Varoluş krizi içinde Osmanlı İmparatorluğu (1768-1826). K. Kreiser ve C. H. Neumann (Ed.), Küçük Türkiye tarihi. Translator Y. Emre Gürbüz. İstanbul: İletişim Publishing, 217-241.

Okman, C. (2012). Türk dış politikası-trendler, çerçeveler ve uygulama süreçleri üzerinde genellemeler (1815-2009). S. Gülden Ayman (Ed.). Mekân, kimlik, güç ve dış politika. İstanbul: Yalın Publishing, 265-323.

Oran, B. (2011). 1919-1923: Kurtuluş yılları. B. Oran (Ed.). Türk dış politikası Cilt I: 1919-1980. İstanbul: İletişim Publishing, 95-239.

Parla, T. (2008). Türkiye’de siyasal kültürün resmi kaynaklarl/cilt 3: Kemalist tek-parti ideolojisi ve CHP'nin Altı Ok'u. İstanbul: Deniz Publishing.

Rumelili B. and U. C. Adısönmez. (2020). Uluslararası ilişkilerde kimlik-güvenlik ilişkisine dair yeni bir paradigma: Ontolojik güvenlik teorisi. Uluslararası İlişkiler Dergisi. 17 (66), 23-39.

Sander, O. (2006). Türkiye’nin dış politikası. M. Fırat (Ed.). Ankara: İmge Publishing.

Seamon, D. and Sowers, J. (2008). Place and placelessness, Edward Relph. P. Hubbard, R. Kitchen, G. Vallentine (Eds.). Human Geography. London: Sage, 43-51.

Subotic, J. (2016). Narrative, ontological security, and foreign policy change. Foreign Policy Analysis. 12 (4), 610-627.

Taşdemir, S. (2015). Türkiye Cumhuriyeti'nin doğum belgesi: Amasya tamimi. Journal of Atatürk Research Center. 21 (63), 1071-1889.

Tetik, M. O. (2018). Zeytindalı operasyonu ve ontolojik güvenlik. M. Akif Okur (Ed.). Güvenlik, kargaşa ve belirsizlik çă̆ında nereye?. İstanbul: Kocav Publishing, 105-118. 
Tunaya, T. Z. (2016). Türkiye'nin siyasi hayatında batılllaşma hareketleri. İstanbul: İstanbul Bilgi University Press.

Türkiye Büyük Millet Meclisi. (2015). Milli egemenlik belgeleri. Sefer Yazıcı, Ankara: TBMM Publishing.

Türkiye Büyük Millet Meclisi Zabıt Ceridesi, 15, 2nd Term, 3rd Session, 69th Meeting, 4th March 1925. Retrieved from

Zarakol A. (2016). States and ontological security: A historical rethinking. Cooperation and Conflict. 52 (1), 1-21.

\section{Makale Bilgi Formu}

Yazar(lar)ın Katkıları: Makaleye tüm yazarlar eşit katkı sağlamıştır.

Çıkar Çatışması Bildirimi: Yazarlar tarafından potansiyel çıkar çatışması bildirilmemiştir.

Destek/Destekleyen Kuruluşlar: Bu araştırma için herhangi bir kamu kuruluşundan, özel veya kâr amacı gütmeyen sektörlerden hibe alınmamıştır.

Etik Onay ve Katılımcı Rızası: Çalışmanın etik kurul belgesine ihtiyacı olmadığı yazarlar tarafindan belirtilmiştir.

$\mathrm{Bu}$ çalışmanın yazım sürecinde bilimsel, etik ve alıntı kurallarına uyulmuş; toplanan veriler üzerinde herhangi bir tahrifat yapılmamış, karşılaşılacak tüm etik ihlallerde "Universal Jounal of History and Culture" hiçbir sorumluluğu olmayıp, tüm sorumluluk yazarlara aittir. 